\title{
ARCANGELO SPAGNA'S “PERFETTO MELODRAMMA SPIRITUALE" AS SEEN ON THE EXAMPLE OF TWO VERSIONS OF HIS ORATORIO BASED ON THE BOOK OF JUDITH*
}

Arcangelo Spagna (1632-1726) is one of the best known figures in the history of Baroque Italian oratorios, a status owed mostly to his short but celebrated treatise Discorso [dogmatico] intorno a gl'Oratorii. As the only instance of extended theoretical reflection on this important literary and musical genre, the Discorso has attracted considerable critical attention. ${ }^{1}$ Spagna published his work in 1706 in Rome together with volume 1 of Oratorii overo melodrammi sacri, a collection of his 12 oratorios. The third oratorio in that collection, L'Amazone hebrea nelle glorie di Giuditta, ${ }^{2}$ deals with a subject taken from the Book of Judith, a common source of plots in 17th- and 18th-century Italian oratorios and a cultural phenomenon being currently researched by us as part of a broader project. ${ }^{3}$ In the course of our research a different version of this libretto has been uncovered, published anonymously (music and text) under a different title:

This article has been written as part of a research project entitled The Book of Judith in Italian Baroque Oratorios (1621-ca1750) (2011/01/B/HS2/04723) financed by National Science Centre in Kraków, Poland.

1 Recent literature includes, among others, SMITHER, Howard E. The Oratorio in the Baroque Era. Italy - Vienna - Paris. Chapel Hill: The University of North Carolina Press, 1977, p. 294-300; ZANETTI, Roberto. La Musica Italiana nel Settecento, vol. 2. Torino: Bramante Editrice, 1978, p. 667-672; HERCZOG, Johann. Il perfetto melodramma spirituale. L'oratorio italiano nel suo periodo classico. Rome: IBIMUS, 2013, p. 78-87.

SPAGNA, Arcangelo. Oratorii overo melodrammi sacri con un discorso dogmatico intorno l'istessa materia, facs. ed. by Johann Herczog. Lucca: Libreria Musicale Italiana, 1993 (Musurgiana, 25) [Libro primo], p. 55-70.

In 1621-1734, 9 drammi per musica and 54 different oratorios and Italian dialogues (both in lingua volgare and in Latin) based on the Book of Judith have been identified. Some were used more than once (and some even repeatedly) for various performances and editions. In 1734-1764, i.e. in the period which felt the early impact of Metastasio's famous oratorio $L a$ Betulia liberata, at least 7 new libretti were written, followed by almost 20 years in which we find nothing but the reception of Metastasio's work. New treatments of Judith's story in the Italian oratorio repertoire did not begin to appear until after 1780, when Metastasio's model of the opera and oratorio libretto was going slowly out of fashion. 
GIUDITTA/TRIONFATRICE / D'OLOFERNE / ORATORIO / DA CANTARSI NELLA VENERABIL COMPAGNIA/ DELL' / ARCANGIOLO RAFFAELLO / DETTA DELLA SCALA / La sera de'31. Dicembre 1701. / [vignette] / IN FIRENZE. MDCCI. / Per Vincenzio Vangelisti. Con licenza de' Superiori. ${ }^{4}$

This is a third case which confirms the fact that Spagna carried out extensive editing work when preparing his oratorios for print in 1706. Earlier counterparts differing from versions known from the Rome edition can also be found for the three-act dramma musicale entitled Il trionfo della fede nel martirio de' Santi Eustachio, e compagni ${ }^{5}$ as well as for Il trionfo dell'honestà ne gl'avvenimenti della casta Susanna. ${ }^{6}$ Several other oratorios by Spagna published in his twovolume Oratorii overo Melodrammi sacri are likewise attested in earlier printed editions. In the chronological order, these include: Oratorio de' Santi Martiri Mario, Marta, Audiface et Abbaco Nobili Persiani (Rome 1682), Oratorio de' Santi Martiri Papia, e Mauro. Dedicato all'eminentiss. e reverendiss. Signor Cardinal Pietro Ottobono Vicecancelliero di Santa Chiesa, e pronepote di Nostro Signore Alessandro 8. (Rome 1690), Aman delusus. Oratorium. Musicis modulis accomodatum a D. Philippo Amadeo Romano. Canendum in Oratorio Archiconfraternitatis SS. Crucifixi. Feria 6. post dominicam quintam Quadragesimae anni 1699 (Rome 1699) and S. Vittoria et Acisclo Martiri di Cordova (Urbino 1703; published as Oratorio de' Santi Martiri di Cordoua Vittoria et Acisclo, Rome 1704). However, no detailed comparative analysis of those works versus their 1706 edition counterparts is available.

Il trionfo della fede nel martirio de' Santi Eustachio, e compagni, published in 1671 in Spoleto as Il Santo Eustachio overo Il trionfo delle fede nel martirio del sudetto Santo, e Compagni ${ }^{7}$ contains particularly numerous changes to the arias, ${ }^{8}$ a fact which documents the rapid formal and stylistic evolution of the aria genre in the closing decades of the 17th-century. Il trionfo dell'honestà had been previously published as Susanna condannata ingiustamente da' giudici e liberata da Daniello. Oratorio a sei voci da cantarsi nella chiesa de' Padri della Congregazione dell'Oratorio di S. Filippo Neri. Musica del sig. D. Giuseppe Micherelli

4 Copy in I-Rn, 35.4.L.15.4. Missing from: SARTORI, Claudio. I libretti italiani a stampa dalle origini al 1800. Catalogo analitico con 16 indici, vols. I-VII. Cuneo: Bertola\&Locatelli, 1990-1994 and from the reconstruction of the repertoire of Florence confraternities: HILL, John Walter. Oratory Music in Florence, III: The Confraternities from 1655 to 1785 . Acta Musicologica, 1986 (58) no. 1, p. 129-179.

5 SPAGNA, op. cit., [Libro secondo, Oratorio XII.], p. 182-220.

6 SPAGNA, op. cit., [Libro primo, Oratorio II.], p. 40-54.

7 Copy of the libretto in I-MOe, 70.F.7.2.

8 Cf. SARNELLI, Mauro. Dai Barberini all'età dell'Arcadia. Nuova indagini sulla poetica drammaturgico-musicale sacra di Arcangelo Spagna. In Musikstadt Rom. Geschichte - Forschung - Perspektiven. Beiträge der Tagung »Rom - Die Ewige Stadt im Brennpunkt der aktuellen musikwissenschaftlichen Forschung " am Deutschen Historischen Institut in Rom, 28.-30. September 2004, ed. Markus Engelhardt. Kassel: Bärenreiter-Verlag, 2011, p. $263-$ 305 (Analecta Musicologica, 45). 
[Micarelli] di Roma in 1693 in Florence. Also, two manuscript copies of the work survive in the libretto collections of the Biblioteca Vallicelliana in Rome. When compared to the printed 1706 edition, these show changes not only to the structure of the arias, but also more some far-reaching differences in terms of the piece's dramatic structure, such as the presence of a "hidden" Narrator. ${ }^{9}$ Spagna gives the role of the Narrator partly to the chorus and secondary characters (a narrative alto part has been identified in the course of libretto as one of Susanna's companions). ${ }^{10}$ Besides he uses choruses to close each of the parts, ${ }^{11}$ a practice he would later discourage in his treatise. ${ }^{12}$ It would also be interesting to compare the manuscript sources and the Roman printed edition of the libretto with another print, published in Florence, which will probably be closer to the manuscripts (it names the above-mentioned alto narrative part simply a Testo):
MS. at I-Rv ${ }^{13}$
Florence $1693^{14}$
Rome 1706

[Testo $=$ Seconda Ancella? $(\mathrm{A})$

Susanna (S1)

Testo

Due Ancelle (S2, A)

Susanna

Susanna

Celinda

Damigella di Susanna

Due Vecchi (T, B)

Rosalva

Daniello (?)

Primo Giudice

Primo Vecchio

Secondo Giudice

Secondo Vecchio

[Coro] (a 5)

Daniello

[Coro]

Daniele Profeta

Choro

It is equally interesting to compare the two versions of Spagna's oratorio based on the Book of Judith, an exercise which yields copious material for speculation on how Spagna may have imagined his "perfetto melodramma spirituale" and on the writing date of the libretto to La Giuditta trionfatrice d'Oloferne - for a num-

9 Removing the Narrator from oratorios was one of Spagna's main postulates, one which he implemented as early as 1656 in Oratorio di Debora (La prudenza tra i perigli nell'historia di Debora), and later claimed priority in this respect. However, Christian Speck (SPECK, Christian. Das Italienische Oratorium 1625-1665: Musik und Dichtung. Turnhout: Brepols, 2003 [Speculum Musicae, 9], p. 422.) identified at least seven libretti containing no Narrator role written before 1656 (in addition to 17 such libretti with uncertain dates of composition).

11 Ibidem, p. 426.

12 SPAGNA, op. cit., [Libro primo], p. 16-17.

13 I-Rv, P.1, fol. 299r-308v and P.4. Cf. MORELLI, Arnaldo. Il Theatro spirituale ed altre raccolte di testi per oratorio romani del Seicento. Rivista Italiana di Musicologia, 1986 no. 1, p. 61-143 (Items 34 and 152); SPECK, op. cit., Item 165: one of the parts of this oratorio, known as Cantata spirituale. Per pp. Filippo Neri, is also attested in the inventory of the Oratorians of Bologna as a work sent in from Rome $(<1682)$. Cf. also MISCHIATI, Oscar. Per una storia dell'oratorio a Bologna: Tre inventari del 1620, 1622 e 1682. Collectanea historiae musicae, 1963 (III), p. 131-170 (Items 352). See also SPECK, op. cit., p. 466 (pos. 165). 
ber of reasons, the date of the Florence edition (1701), just five years before the Rome edition, seems unlikely to offer useful clues.

The two libretti are of comparable length - Giuditta trionfatrice d'Oloferne is 450 lines long, and L'Amazone hebrea is 429 lines long. This is close to the optimum length of an oratorio text recommended by Spagna in his treatise (unlike the libretto of Susanna condannata ingiustamente, which is much longer than later version Il trionfo dell'honestà, published in Oratorii overo Melodrammi sacri).$^{15}$ Neither version contains a Narrator; both seem to implement Spagna's favoured idea of the oratorio as a "melodramma sacro", i.e. a fully dramatized religious piece. As he was reworking the older version, Spagna was presumably looking for ways to make it a "perfetto Melodramma sacro". ${ }^{16}$ Accordingly, I will present the two texts in the wider context of the developing genre of the oratorio libretto in the second half of the 17th century by closely analysing Spagna's editorial strategies and examining their consequences.

\section{Interlocutori}

The list of the dramatis personae in the Florence printed edition lists three named characters: Giuditta, Ozia and Oloferne, and three collective characters: Coro di Soldati di Betulia, Coro di Soldati Assiri and Coro di Lottatori Assiri. Within the text itself, several other roles can be identified. Such appearances are minor and generic: in Part One we find a Capitano di Betulia and an Altro Capitano di Betulia (the text also identifies a Capitano 2. di Betulia, presumably one and same character), and, in Part Two, a Capitano Assirio and Due Assiri. Their parts are extensions of chorus passages containing expository material such as the opinions and comments of the collective characters (Israelites or Assyrians), often of narrative nature. At times, Spagna seems to individualize selected members of the chorus - there are numerous solo passages to be sung by Uno [Primo], Secondo, Terzo, Quarto, or even Quinto del Coro. To sum up, choruses (with the lines of the above mentioned accidental characters included) have almost a fourth of all the lines of poetry in the piece and they are often of purely narrative nature as can be seen in the example cited below (1701: vv. 108-118):

Pr. di Bet. [= Primo del Coro di Soldati di Betulia]

Cinge Barbaro assedio

Di Betulia le Mura,

E in sì grave sciagura

Sola speranza, è non sperar rimedio.

Di cristallino umore

Arida è già ogni vena,

\section{Barbarous besiegement tightens}

The walls of Bethulia,

And in so grave situation

One can only hope, but there is no hope.

All our springs are dried-up,

There is no drop of liguid in them,

15 SPECK, op. cit., p. 424.

16 SPAGNA, op. cit., [Discorso], p. 8. 
E sol brama l'arena

And the soil wants some water,

L'acque, che sparge in doppio rivo il core. Which can only be supplied with our tears. Ozia

Il Sommo Dio dalla Superna Sfera A gl'Eserciti impera.

The Great God from Heavens

Commands the troops.

\section{Due di Bet. [Due del Coro di Soldati di Betulia]}

Miriam il Ciel solo a punirci intento[.] But we see Heavens wanting only

to punish us.

In 1701, when La Giuditta trionfatrice d'Oloferne was performed in Florence, the oratorio must have seemed very outmoded: this kind of structure was rather characteristic of operas composed in the first half of the 17th century (or in the middle of the 17th century at the latest), including the productions of the Barberini Theatre in Rome from the time of the famous carnival held to welcome Christina, Queen of Sweden, and later from the short pontificate of Giulio Rospigliosi (Pope Clement IX). To remain with works topically connected with the Book of Judith, a comparably extensive use of choruses (sung by individual singers owing to the more modest nature of such performances) can be found in libretti from the mid-17th century - such as the anonymous Oratorio di Giuditta from the collection Il Theatro spirituale..$^{17}$ In later works, choruses embellished with various minor parts can be found in pieces such as La Giuditta by Maurizio Cazzati (Bologna 1668; based on Andrea Salvadori's La Giuditta, performed with music by Marco da Gagliano in Florence in 1626) ${ }^{18}$ and in the Latin oratorios from the 1670 s and 1680s, e.g. the anonymous Iudith (Rome 1672) ${ }^{19}$ or Iudith Bethuliae obsessae propugnatricis with a libretto by Filippo Capistrelli and music by Innocenzo Fede (Rome 1685). ${ }^{20}$ However, such choruses gradually disappear from oratorio libretti even in those cases where they seem naturally suited for their biblical subjects. This is in keeping with a tendency, introduced since the mid-17thcentury by Venetian opera, to use the word Coro in the list of dramatis personae in the sense of supernumeraries (courtiers, ladies of the court, soldiers, priests etc.). This tendency is perfectly illustrated by the soloistic oratorios by Giacomo Antonio Bergamori (libretto) and Giovanni Paolo Colonna (music) entitled La

17 N. ${ }^{\circ}$ 7. Oratorio di Giuditta. In IL THEATRO SPIRITVALE / Ove salendo svl Monte di Parnaso / si Godono le Sacre Muse / et Armonie del Cielo / Tomo 2o / Diviso in trè Libri / Dove si contengono una scelta di alcuni / oratorij, composti da Poeti molto pij et eccel- / lenti, Pieni di molte belle sentenze e San- / ti ammaestramenti, variati di bellissime / Ariette musicali; Aditandoci le divine / melodie, et armonie eterne. / Or[ator]i. 1677. Antichi. (I-Rv, MS. P.2, pp. 59-70). Ch. Speck (op. cit., p. XXX) dates those oratorios to the 1640s-1650s.

Copies of libretti consulted: I-Rvat, Barb.lat.3839, fol. 66r-94v (mss copy of azzione sacra La Giuditta by Andrea Salvadori), I-Rn, 35.4.L.15.5 (Cazzati, Bologna 1668) and I-Bc, Lo. 7437 (Cazzati, Mantua 1672).

19 Libretto copy consulted: I-Rn, Misc. Valenti 690.22.

20 Libretto copy consulted: I-Rli, 171.I.19.24. 
Bettuglia liberata (Bologna 1690) ${ }^{21}$ and La caduta di Gerusalemme sotto l'imperio di Sedecia ultimo re d'Israelle (Modena 1688, Bologna 1690), ${ }^{22}$ which are based on stories involving ancient Israel's conflicts with foreign invaders. Where the Coro does appear in oratorios from that time, its lines are usually limited to short rejoinders (sometimes only a single line in length) to words spoken by the main heroes. For instance, this is the case in Iudith de Holoferne triumphus by Giovanni Bartolomeo Durante (libretto) and Giuseppe Scalmani (music) (Rome 1685), ${ }^{23}$ the anonymous Iudith de Holoferne triumphans with music by Francesco Gasparini (Rome 1689), ${ }^{24}$ and particularly in anonymous Iudith Bethuliae obsessae propugnatricis triumphus with music by Flavio Lanciani (Rome 1689). ${ }^{25}$ Sometimes the chorus also has more lines in Italian oratorios sung in provincial towns and cities, such as the anonymous La Giuditta (Lucca 1700), ${ }^{26}$ where chorus lines replace the Narrator (e.g. in the description of the beauty of the heroine early in Part Two) and heighten the drama by representing two hostile groups of characters, the Israelites (Coro di Giuditta) and the Assyrians (Coro d'Oloferne).

However, in Florence several other oratorios based on Liber Iudithae were performed before 1701 and all of them were more modern in their dramatic structure than Spagna's La Giuditta trionfatrice d'Oloferne. One can cite here Cosimo Bani's La strage degli Assiri sotto Betulia (1692), ${ }^{27}$ Bartolomeo Nencini's and Alessandro Melani's Giuditta (1693), ${ }^{28}$ Girolamo Gigli's La Giuditta (undated libretto, probably of 1694) ${ }^{29}$ and Pietro Ottoboni's and Alessandro Scarlatti's $L a$ Giuditta (1700), ${ }^{30}$ all without Testo and with only accidental use of Cori, suitable to be sung even by the ensemble of soloists. It should also be stressed that the oldest libretto, Nencini's Giuditta premiered in Rome in 1675 as La morte d'Oloferne ${ }^{31}$ was deeply changed for its Florentine performance. The most im-

21 Libretto copy consulted: I-Bc, Lo. 1261. Also known as Giudith from a performance in Modena in 1684 (libretto consulted: I-MOe, 83.I.006.05). By comparing the two versions we may suppose that the Bologna version, though known from a later printed libretto, is the full and original version, whereas the Mantua performance involved a much shorter version with much of the Narrator's moralising commentary curtailed.

See BERGAMORI, G. A. (libr.) - Colonna, G. P. (mus.). La caduta di Gerusalemme sotto l'imperio di Sedecia ultimo re d'Israelle, ed. facs. ms in F-Pn, D. 2303, Introduction Joyce Lynn Johnson. New York \& London: Garland Publishing, 1986 (The Italian Oratorio 1650$1800,5)$.

23 Libretto copy consulted: I-Rli, 171.I.19.25.

24 Libretto copy consulted: I-Rc, Mus. 718.27.

25 Libretto copy consulted: I-Bc, Lo 7468.

26 Libretto copy consulted: I-Lg, Busta 568.23.

27 Libretto copy consulted: I-Rn, 35.4.D.2.14.

28 Libretto copy consulted: I-Vgc, ROL.0453.01.

29 Libretto copy consulted: I-Fm, 2292.22.

30 Libretto copies consulted: I-Rn, 40.8.I.15.1 (Compagnia della Purificazione); I-Rig, Rar. Libr. Orat. 18 Jh -8- (Compagnia di S. Caterina).

31 Libretto copy consulted: I-Rvat, Chigi IV.2304 (it documents a performance in Ferrara in 
portant alterations occurred exactly within its Cori and roles of Primo and Secondo Israelita: choruses were partially removed while the lines sung by Primo or Secondo Israelita were either cut off or assigned to newly created character of Simeone, much more individual and substantial in reference to its earlier counterparts. So Spagna's La Giuditta trionfatrice d'Oloferne is a real treasure for musicologists as it seems that as late as in 1701 it was published in its archaic dramatic structure still unaltered.

Spagna's principal editing goal seems to have involved reducing the number of lines sung by the chorus and accidental roles. Because the listeners who follow the plot of an oratorio as a non-theatrical piece would have struggled to make sense of too many speaking roles, Spagna suggested that the number of them should not exceed five. ${ }^{32}$ Accordingly, he either removed or redistributed the lines sung by accidental characters giving them either to Ozia or to Vagao or Judith's Nutrice (Nurse), two new fully fledged characters, each of whom appears in both Parts of the oratorio. ${ }^{33} \mathrm{He}$ did it with a great care as can be seen on the example of the transformation of a passage sung by Capitano di Betulia into the aria put in mouth of Nutrice:

1701: vv. 71-76

Cap. di Bet.

Già strage insesta

Le Trombe intuonano,

Ecco funesta

Gl'Antri risuonano;

E minaccian per tutto

Le squadre oppugnatrici incen- Le nemiche falangi, incendio, dio, e lutto.

1706: vv. 85-92

\begin{tabular}{|c|c|}
\hline \multicolumn{2}{|c|}{ [Nutrice] } \\
\hline Già strage horribile & Now a horrible defeat \\
\hline Il suon terribile & A terrible sound \\
\hline Le Trombe intuonano. & Of trumpets announces. \\
\hline Con echo flebile & With a funeral/ plaintive echo \\
\hline Del sesso debole & Of the weak sex \\
\hline Gl'antri risuonano. Già \&c. & All caves resound. \\
\hline E minaccian per tutto & And the enemy's armies \\
\hline $\begin{array}{l}\text { Le nemiche falangi, incendio, } \\
\text { e lutto. }\end{array}$ & $\begin{array}{l}\text { Menace all with fire and } \\
\text { mourning. }\end{array}$ \\
\hline
\end{tabular}

Spagna did the same thing with his Cori: in L'Amazone hebrea the chorus sings a total of just 22 lines, mostly in 1-3 line interjections (which is similar to other oratorios published in Oratorii overo Melodrammi sacri). ${ }^{34}$ The only

1675 as there is no Roman edition from the very same year).

SPAGNA, op. cit., [Discorso], p. 16.

Similar interventions on the part of Spagna have been noted in Oratorio de' Santi Martiri Mario, Marta, Audiface et Abbaco Nobili Persiani (Rome 1682) - cf. SARNELLI, Mauro. Percorsi dell'oratorio per musica come genere letterario fra Sei e Settecento. In Percorsi dell'oratorio romano. Da "historia sacra" a melodramma spirituale, ed. Saverio Franchi. Roma: IBIMUS, 2002, p. 137-197 (Colloquia, 1).

In some of Spagna's oratorios, the Coro is not even listed in the dramatis personae despite appearing in the libretto (though obviously in a much curtailed role); it was presumably sung by a tutti of the soloists. 
chorus appearances which remain untouched are those with some kind of dramatic potential, such as the chorus of Betulian soldiers debating whether they should surrender or make a last stand, which makes its first appearance - as additionally indicated by Spagna in L'Amazone hebrea - "come da lungi" ["as if heard from a distance"] (1701: vv. 54-70; 1706: vv. 43-57). In his Discorso, Spagna seems uninterested in the Coro as an important component of the oratorio - he must have been aware of the contemporary trend to remove the chorus from dramatic pieces; instead, he only mentions the practice of including a closing polyphonic madrigal (sung by tutti) containing the moral of the oratorio, a practice also referred to as a Coro at the time which Spagna recommends dropping it in favour of an aria. Spagna's disinclination to use closing Cori in either of the two parts of the oratorio is already evident in his La Giuditta trionfatrice d'Oloferne: the closing madrigals (with lines in heptameter and undecameter) which explain the religious and moral significance of the events, are given (with no dramatic justification) to Ozia, and the chorus merely repeats his closing lines (cf. 1701: vv. 227-235, vv. 435-442). ${ }^{35}$ However, Spagna did not introduce the fashionable aria ending until L'Amazone hebrea, where it only appears at the end of Part One - however, he introduced there not a typical arietta allegra that he had recommended for a pleasant ending of an oratorio but aria with a religious message.

Still, the overall dramaturgical effect of the changes is not exactly felicitous. The new characters are not well-integrated, and their dramatic function seems incongruent - i.e. Vagao's role is still very unindividualized one as it consists mainly of the simple "borrowings" from passages sung earlier by accindental characters while the Nurse is not only Judith's confidante (a role expansion created with new lines of poetry added towards the end of Part One of L'Amazone hebrea), but also the spokeswoman for the people clamouring for Betulia's surrender.

\begin{abstract}
Abbellimenti
In order to avoid turning libretti into drily factual recountings of biblical or hagiographic material, Spagna allowed a necessary degree of licentia poetica to fully dramatising the histories. However, he warned that such ornaments or abbellimenti should not attenuate or obscure the "moralità" (moral) which oratorios should retain from their sacred sources. He also argued against dwelling on episodes involving "amori profani", even when mentioned in the Bible or in the

35 Nonetheless, even one or two lines could be given a sophisticated polyphonic treatment (underappreciated by the contemporaries), such as the closing verse of the oratorio La Giuditta by Pietro Ottoboni with music by Alessandro Scarlatti (Rome 1694). The first segment of this line ("muta in ciel di contenti") is set in canonic imitation, the second ("un mar di pianti"), containing supplementary music material, plays a contrapuntal role. Cf. SCARLATTI, Alessandro. La Giuditta, ed. Lino Bianchi. Roma: De Santis, 1964, p. 162-174 (Gli Oratorii di Alessandro Scarlatti, 1).
\end{abstract}


lives of saints (particularly female ones) - love-related content should be limited to what was strictly necessary, and the listeners were supposed to focus on the character's virtù. Obviously, this principle ensured that oratorios based on the Book of Judith would pose a real challenge. The dramatic components present in the Book of Judith were either the same as the popular (topical) components of the drammi per musica of the day, or at least offered good pretexts for introducing them. ${ }^{36}$ The list below outlines those components and indicates which ones were used by Spagna in the two versions of his oratorio based on Liber Iudithae:

\begin{tabular}{|c|c|c|}
\hline $\begin{array}{l}\text { Book of Judith: motifs and their affinities with contemporary op- } \\
\text { eratic topics or conventions }\end{array}$ & Spagna 1701 & Spagna 1706 \\
\hline $\begin{array}{l}\text { 1. Judith stands up to the elders - she can be portrayed as an Ama- } \\
\text { zon, a donna forte, who subverts social hierarchy: her opposition } \\
\text { can be understood as an assumption of a male role by a female. In } \\
\text { such a case: } \\
\text { 1a. Judith speaks like a commander / politician } \\
\text { 1b. her speech triggers misogynistic comments and provokes suspi- } \\
\text { cions of immorality expressed by other characters }\end{array}$ & $\begin{array}{l}--- \\
---\end{array}$ & $\begin{array}{l}--- \\
+\end{array}$ \\
\hline $\begin{array}{l}\text { 2. Judith puts on her finery: } \\
\text { 2a. introduction of "the mirror scene" }\end{array}$ & + & + \\
\hline $\begin{array}{l}\text { 3. Judith tricks the Assyrians: } \\
\text { 3a. Judith claims to be a refugee } \\
\text { 3b. Judith declares to use her beauty for trickery as opera heroines, } \\
\text { who are open about using beauty and feigned emotions to manipu- } \\
\text { late their enemies }\end{array}$ & --- & + \\
\hline $\begin{array}{l}\text { 4. Judith leaves the city with a faithful maid servant: } \\
\text { 4a. servant supports Judith } \\
\text { 4b. weak and cowardly servant is a foil to brave and strong Judith } \\
\text { 4c. maid servant persuades Judith to commit immorality, like a typi- } \\
\text { cal operatic nurse }\end{array}$ & --- & $\begin{array}{l}\text {--- } \\
+ \text { (connected with } \\
\text { 1b.) } \\
--- \\
\end{array}$ \\
\hline $\begin{array}{l}\text { 5. Holofernes portrayed as: } \\
\text { 5a. a tyrant and a destructive daemon hungry for divine worship } \\
\text { 5b. eroe effeminato (introduction of the motif of Mars defeated by } \\
\text { Venus used ad nauseam in Italian opera) }\end{array}$ & $\begin{array}{l}\text {--- (poss. ele- } \\
\text { ments in 7a. and } \\
\text { 7c.) }\end{array}$ & $\begin{array}{l}\text {--- } \\
\text { in 7a. and 7c.) }\end{array}$ \\
\hline $\begin{array}{l}\text { 6. Holofernes vs servant (Bagoas, officers): } \\
6 \text { a. good servant warns Holofernes against allowing oneself to be } \\
\text { ruled by emotion (this function is sometimes performed by Achior) } \\
6 \text { b. servant who encourages evil deeds and wanton desires }\end{array}$ & $\begin{array}{l}--- \\
---\end{array}$ & $\begin{array}{l}--- \\
---\end{array}$ \\
\hline
\end{tabular}

36 For opera topoi and conventions see: FABBRI, Paolo. Il secolo cantante. Per una storia del libretto d'opera in Italia nel Seicento. Rome: Bulzoni Editore, 2003. (including "tema del tiranno", "scena del sonno", "scena allo specchio") or ROSAND, Ellen. Opera in Seventeenth-Century Venice: The Creation of a Genre. Berkeley-Los Angeles-Oxford: University of California Press, 2007, (including the love duet, the music scene, dream, invocation of a deity). For the "Amazon" opera narratives see FREEMAN, Daniel E. "La guerriera amante": Representations of Amazons and Warrior Queens in Venetian Baroque Opera. The Musical Quarterly, 1996 (80), Issue 3, p. 431-460, and HELLER, Wendy Beth. Chastity, Heroism, and Allure: Women in the Opera of Seventeenth-century Venice, vols. I-II, doctoral dissertation. Brandeis University, 1995 (including an analysis of Francesco Cavalli's Veremonda, l'Amazzone d'Aragona). 


\begin{tabular}{|c|c|c|}
\hline $\begin{array}{l}\text { Book of Judith: motifs and their affinities with contemporary op- } \\
\text { eratic topics or conventions }\end{array}$ & Spagna 1701 & Spagna 1706 \\
\hline $\begin{array}{l}\text { 7. Holofernes in love, while Judith is submissive might be a pretext } \\
\text { to introduce: } \\
\text { 7a. love duet (the love may be feigned by one or both parties) } \\
\text { 7b. love complaint (lamento) of Holofernes } \\
\text { 7c. lavish feast held in honour of Judith with music scene, wedding } \\
\text { panegyric, cheering etc. }\end{array}$ & $\begin{array}{c}+ \\
+-- \\
+ \text { (tournament } \\
\text { and cheering) }\end{array}$ & $\begin{array}{c}\quad+ \\
+-- \\
+ \text { (tournament } \\
\text { and cheering) }\end{array}$ \\
\hline $\begin{array}{l}\text { 8. Holofernes falls asleep = "scena del sonno": } \\
\text { 8a. lullaby which sometimes can be expanded to the size of a inde- } \\
\text { pendent "music scene" } \\
8 \text { b. confrontation of characters, one of which speaks while sleeping } \\
\text { what can produce misunderstanding as the characters speak and } \\
\text { think (dream) of different things }\end{array}$ & -- & --- (Bagoas?) \\
\hline $\begin{array}{l}\text { 9. Judith prays before killing Holofernes: } \\
\text { 9a. introduction of a scene of invocation of the supernatural at a cli- } \\
\text { mactic moment, particularly in vogue in opera if sung by a female } \\
\text { character }\end{array}$ & + & + \\
\hline $\begin{array}{l}\text { 10. Judith slays Holofernes: } \\
\text { 10a. death of a tyrant, which was occasionally depicted on the } \\
\text { stage in operas }\end{array}$ & $\begin{array}{l}+ \text { (extremely } \\
\text { compressed) }\end{array}$ & $\begin{array}{l}+ \text { (even more } \\
\text { compressed) }\end{array}$ \\
\hline
\end{tabular}

As a character, Holofernes attracted a lot of attention from Spagna's contemporary librettists (e.g. La Giuditta by Leone Alberici, published in Orvieto in 1679 or L'Oloferne by Rinaldo Ciallis, Parma 1681). ${ }^{37}$ But Spagna's Oloferne is not particularly vividly drawn and his portrayal remains essentially the same in L'Amazone hebrea. In both, Holofernes is more a soldier than a tyrant. His cruelty is implied by the contents of the Book of Judith rather than shown through his behaviour in oratorio libretto. Eventually, Spagna devotes more space to emphasising Holofernes' pride as commander using numerous panegyrics sung by the Assyrians. His transformation into an eroe effeminato happens imperceptibly - we only notice its effects in his love duet with Judith ("Hai vinto"). The Jewish heroine is a more vivid and interesting creation - in the original version ( $L a$ Giuditta trionfatrice d'Oloferne) Spagna focuses almost exclusively on presenting Judith's virtù (with the possible exception of the love duet). Her beauty and amorous stratagems are very much left to the listener's imagination and knowledge of the content of Liber Iudithae - the only moment of the annoucement that she gives up her widow clothes and ornates herself with fine jewellery is the aria "Io vi depongo homai". But even this is shown by Spagna in military spirit - her jewellery, as Judith declares in the second strophe, becomes her armour. When Holofernes invites Judith for a lavish supper, Spagna introduces the "scene" of the knightly tournament, in fact a very "theatrical" device, used here, however, as an excuse to avoid showing Judith directly taking part in the feast and to present her in the most favourable light. The tournament becomes a metaphor of a life

37 Libretti consulted: I-Ralessandrina, Fondo Antico N.e.117 (Alberici) and I-Mb, Racc. Dramm. Corniani-Algarotti 3569 (Ciallis; performed in the church of the Oratorian fathers in Venice in 1696 or 1697). 
of worldly pleasure and pursuit of honour (the participants are fighting to win a precious sword as a prize), an implicit criticism of Holofernes. Judith watches the tournament "from the sidelines" and comments it. Her admonitions "Cieca, e folle humanità", which foreshadow Holofernes' final catastrophe, are very possibly more aimed at the listeners of the oratorio rather than at the Assyrians. In a very original fashion, this puts Spagna's interpretation of the theme of Judith and Holofernes (as schematic as his portrayal may be) in the broader category of Italian oratorios which interpret this biblical story as an account of the fall of a tyrant, one of the most prevalent topoi used to depict the idea of vanitas in Baroque literature - suffice it to mention works such as La Giuditta by Cazzati, La Giuditta by Alberici, L'Oloferne by Rinaldo Ciallis, the anonymous dialogue La superbia abbattuta (Palermo 1685) (38 $^{38}$ or Giuditta by Giacomo Cossa (Rome 1705). ${ }^{39}$ Judith's prayer "Tu Signor, ch'il petto mio" (or in 1706: "Tu vigore al braccio mio") dispels any potential doubt about the divine inspiration for her dire deed.

To sum up, Judith's portrayal in La Giuditta trionfatrice d'Oloferne follows closely Spagna's own prescriptions to omit unnecessary concentration on "affetti profani". It can be compared with Fede Galizia's beautiful picture Judith with the head of Holofernes (1596 and 1601) ${ }^{40}$ - here the heroine is pompously dressed and the presence of her nurse with meaningful Harpocrates' gesture indicates that in Judith's story there are many things about which it would be better not to talk to much. What a perfect imagination of this characteristic tension between disturbing and heroic elements of the Book of Judith which could cause so many difficulties for any librettist who cared about moral pureness of his libretto.

In L'Amazone hebrea Judith's portrayal as perfect and faultless in nearly every respect is partly debunked. Thanks to the presence of the Nurse we learn that the mission Judith undertakes exceeds a woman's strength (monologue and aria of the Nurse, "Dalle spade esposto a un lampo"; vv. 183-192), that she is so richly dressed that it seems she is going to attend a banquet and, finally, that she plans to deceive the Assyrians (duet between Judith and the Nurse, "Dove, o misere, lo scampo", announced beforehand in the recitative "finger convien" ["one should dissimulate"]; vv. 257-266). However, to balance out such hints of morally suspect motivations, Spagna concludes Part One with a new religious aria, "O Signor, tua luce fida", which emphasises the divine inspiration of Judith's deed.

The canon could be inspired to introduce those troubling abbellimenti by oratorio La Giuditta written by Antonio Ottoboni (Rome, Palazzo Cancelleria 1697 or 1695?), which contains a Nurse with a bitter, misogynistic monologue (vv. 24-32), Judith in the "mirror scene" and heroine's feigned tears as a refugee

38 Libretto consulted: I-Rig, Rar. Libr. Orat. 17.Jh.-18-.

39 Libretto consulted: I-Rig, Rar.Libr.Orat.18.Jh.-66-.

40 See http://en.wikipedia.org/wiki/File:Judith_with_the_head_of_Holofernes.jpg (earlier version in Sarasota/ Florida, Ringling Museum of Art, the later one can be found in Rome, in Galleria Borghese). 
(vv. 78-99). ${ }^{41}$ Spagna used those motifs, probably taking into consideration that an oratorio libretto should be no less attractive than an operatic one. However, in the same time he still tried to follow his own postulates by exercising moderation and providing religious commentary emphasized strongly enough to preserve $\mathrm{Ju}$ dith's image as an "Amazzone di Dio" not allowing her to become to openly an operatic Amazon to which she came too close in the libretti of his patron, Pietro Ottoboni, and especially in that of his father, Antonio. ${ }^{42}$

\section{Numeri chiusi (arias)}

The poetic structure of many arias in La Giuditta trionfatrice d'Oloferne follows the forms developed in Venetian opera around the middle of the 17th century. Certain passages stand out, such as Judith's opposition to the wavering Betulians containing a thoughtful refrain in the recitative "Ah miseri tacete" (1701: vv. 166-182), a device usually written by composers in an arioso or even aria style, ${ }^{43}$ or the aforementioned admonitions in "Cieca, e folle humanità", which intersperse the tournament "scene" as the refrain of Judith's aria and between other character's exchanges (1701: vv. 356-387; 1706: vv. 333-368). There are also many strophic arias, some of them containing the archaic strophe structure with concluding couplets written in a metre characteristic of recitatives. ${ }^{44}$ This poetic structure can be found for example in Judith's two-strophe lamentation at Holofernes' feet "Di quel Cielo i rai lucenti" $(8 \mathrm{a}-4 \mathrm{a}-4 \mathrm{~b}-4 \mathrm{~b} / 7 \mathrm{c}-11 \mathrm{c}$, usually set to music in the $\mathrm{ABB}^{\prime} \mathrm{CC}$ ' form). Interestingly, not all the arias (including the one just mentioned) were updated to more modern patterns in the 1706 edition (e.g. by using such simple interventions as the removal of the second strophe or the removal of the concluding refrain in the 7/11-syllabic metre). Judith has a particularly high number of such arias, possibly an indication of Spagna's intention to give his eponymous heroine a poetically archaic air as one of the possible way of emphasising her virtù.

41 Line numbers refer to the reconstructed text: DUBOWY, Norbert. Le due 'Giuditte' di Alessandro Scarlatti: due diverse concezioni dell'oratorio. In L'Oratorio musicale italiano e i suoi contesti (secc. XVII-XVIII). Atti del convegno internazionale. Perugia, Sagra Musicale Umbra, 18-20 settembre 1997, ed. Paola Besutti Florence: Leo s. Olschki Editore, 2002, p. 259-288: 276-288 (Quaderni della Rivista Italiana di Musicologia, 35).

42 For more information on Judith as an Amazon see: RYSZKA-KOMARNICKA, Anna. Judyta i Holofernes - oratoryjne odpowiedniki bohaterów barokowej opery, Amazonki i Tyrana. Polski Rocznik Muzykologiczny, 2012, p. 123-145. ROSAND, op. cit., p. 296-298.

44 Ibidem, p. 285-290. 


\section{Summary}

Both versions of Spagna's Book of Judith oratorio show that Spagna saw mid17th-century melodramma as an exemplary model. He made obvious efforts to reconcile its principles with the burgeoning dramma per musica and oratorio forms of the second half of the 17th century, especially with the trends he was familiar with from his service to Cardinal Pietro Ottoboni. It would be extremely compelling to know to which extention Spagna's ideas on oratorio exposed in his treatise were influenced by the oratorio repertoire performed at Palazzo della Cancelleria he had witnessed to? It seems that his openness on a presence of at least certain abbellimenti in the oratorios (as proved also by his L'Amazone hebrea) might be reinforced by the examples of such librettos legitimated by the ecclesiastic authority of one of the most powerful cardinals of those days whom he served.

It also seems that the original version entitled La Giuditta trionfatrice d'Oloferne may have been written even in the 1660s, shortly after Oratorio di Debora, which would corroborate the thesis that Spagna may have arranged the oratorios in Oratorii overo melodrammi sacri chronologically, in the order in which they were written. ${ }^{45}$ It is also highly probable that La Giuditta trionfatrice d'Oloferne had been performed in Rome many years before its Florentine presentation (as indicates likewise the example of Susanna condannata ingiustamente da' giudici e liberata da Daniello, namely its libretto preserved in Rome in manuscript copy in I-Rv). However, it is very difficult to appraise his L'Amazone hebrea. In some ways Spagna's treatment still remains undeniably original (e.g. the "tournament scene"). It also reveals his obvious efforts to make his oratorio dramatically attractive while maintaining the religious nature of the story (new religious arias appeared not only in the role of Giuditta but in that of Ozia as well). But it is only Judith who stands very much at the centre of his dramatic interest as a remarkable character: a preacher and a woman who is both beautiful and brave, both pious and wise. ${ }^{46}$ But in terms of overall structure and characterization of other protagonists Spagna falls short of creating a libretto as effective and coherent as those aforementioned ones by Gigli or Bergamori, two other librettists who, like Spagna, tried in their different ways to make the oratorio libretto attractive to contemporary listeners without losing sight of its religious and moral nature. ${ }^{47} \mathrm{I}$ do not mean that Spagna was a minor librettist ${ }^{48}$ but his road to a "perfetto melodramma spirituale" - at least in the case of this oratorio based on such a difficult subject as the Book of Judith - seems to have been a particularly rocky one. And it might be a paradoxe that exactly in the year of the publication of Spagna's Oratorii overo melodrammi sacri, within the mecenate of Pietro

HERCZOG, Johann. Introduzione. In SPAGNA, op. cit., p. XII-XIV. 
Ottoboni emerged another libretto based on the Book of Judith which occurred to be both attractive and free from any particular abbellimento of operatic or profane nature - it was La Giuditta by abbate Giacomo Buonaccorsi performed in Palazzo della Cancelleria on March $17^{\text {th }}, 1706$ with music probably by Alessandro Scarlatti ${ }^{49}$ and dedicated to marchese Francesco Maria Ruspoli. Judith's portrayal in this libretto goes perfectly with the paths of an official way the biblical heroine was painted, modestly dressed and even not particularly bejewelled, on the walls of Roman churches, personifying either Virgin Mary or chiesa militante. One can cite here such examples as Domenichino's Judith showing the head of Holofernes to Bethulians from Bandini Chapel in the Church of St Sylvester at the Quirinal (ca 1628), Andrea Pozzo's The triumph of Judith from Jesuits' Church of St. Ignatius of Loyola (ca 1685-88) and Daniele Seiter's Judith with the head of Holofernes from Oratorians' Church of Santa Maria in Vallicella (ca 1697-1700). Buonaccorsi's libretto with its highly original, ascetic drammaturgical shape ${ }^{50}$ tourned out to be very popular in the first half of $18^{\text {th }}$ century and became a sort of a forerunner of Bernardino Maddali's Il trionfo di Giuditta (Vienna, 1723, music by Giuseppe Porsile) and Pietro Metastasio's La Betulia liberata written nearly 30 years later (Vienna, 1734, music by Georg von Reutter jr.) ${ }^{51}$ whereas Spagna's both La Giuditta trionfatrice and L'Amazone ebrea felt into oblivion.

Anna Ryszka-Komarnicka (ryszkom@hotmail.com), Instytut Muzykologii, Uniwersytet Warszawski.

49 Libretto consulted: I-Rn, 34.1.L.38.2. The only score preserved (D-MÜp, Sant HS 409) has, however, the name of the composer Pietro Paolo Bencini written down on its title page. The score mentioned above corresponds to the libretto print from Montefiascone from 1720 (copy consulted: I-Rvat, R.G.Miscell.B.52.14).

50 STAFFIERI, Gloria. L'oratorio musicale a Roma (1683-1713): documenti, aspetti e problemi, MA thesis. Roma: Università di Roma "La Sapienza", 1985/86, vol. I, p. 110-117.

51 More on this libretto in the context mentioned above: RYSZKA-KOMARNICKA, Anna. Metastasio's 'La Betulia liberata' (1734) in the Context of Selected Late-Baroque 'trionfi di Giuditta' held in Rome. In La cultura del barroco español e iberoamericano y su contexto europeo, eds. Kazimierz Sabik - Karolina Kumor. Varsovia: Instituto de Estudios Ibericos e Iberoamericanos de la Universidad de Varsovia, 2010, p. 673-682. 


\section{ABSTRACT \\ ARCANGELO SPAGNA'S "PERFETTO MELODRAMMA SPIRITUALE" AS SEEN ON THE EXAMPLE OF TWO VERSIONS OF HIS ORATORIO BASED ON THE BOOK OF JUDITH}

Arcangelo Spagna's Oratori overo melodrammi sacri con un discorso dogmatico intorno l'istessa materia is always considered a milestone in a history of a Baroque oratorio. Published in Rome in 1706, it consisted of the oratorios written probably many years before that date. Recently earlier versions of two works from Spagna's Oratori has been found and described by scholars: the case of Il trionfo dell'onestà negl'avvenimenti della casta Susanna (Christian Speck) and Il trionfo della fede nel martirio de' santi Eustachio e compagni (Mauro Sarnelli). My research allow me to identified the third such case: an earlier version of L'Amazone hebrea nelle glorie di Giuditta, entitled Giuditta trionfatrice d'Oloferne, published in 1701 in Florence. The two versions, although the dates of their publication are very close, differ quite substancially from each other. The dramatic shape of Giuditta trionfatrice d'Oloferne, although without Testo, has many archaic features, proving that it could have been conceived as early as in the sixties or seventies of the $17^{\text {th }}$ century. The comparison of the two versions shows strategies that Spagna employed to make his oratorio more operatic (theatrical) and to preserve its spiritual atmosphere as well. The final version, however, is far from being perfect, especially from dramatic point of view.

Key words

Arcangelo Spagna, baroque oratorio, Book of Judith

\section{Bibliography}

BERGAMORI, G. A. (libr.) - Colonna, G. P. (mus.). La caduta di Gerusalemme sotto l'imperio di Sedecia ultimo re d'Israelle, ed. facs. ms in F-Pn, D. 2303, Introduction Joyce Lynn Johnson. New York \& London: Garland Publishing, 1986.

DUBOWY, Norbert. Le due 'Giuditte' di Alessandro Scarlatti: due diverse concezioni dell'oratorio. In L'Oratorio musicale italiano e i suoi contesti (secc. XVII-XVIII). Atti del convegno internazionale. Perugia, Sagra Musicale Umbra, 18-20 settembre 1997, ed. Paola Besutti. Florence: Leo s. Olschki Editore, 2002, p. 259-288.

FABBRI, Paolo. Il secolo cantante. Per una storia del libretto d'opera in Italia nel Seicento. Rome: Bulzoni Editore, 2003.

FREEMAN, Daniel E. "La guerriera amante": Representations of Amazons and Warrior Queens in Venetian Baroque Opera. The Musical Quarterly, 1996 (80), Issue 3, p. 431-460.

HELLER, Wendy Beth. Chastity, Heroism, and Allure: Women in the Opera of Seventeenth-century Venice, vols. I-II, doctoral dissertation. Brandeis University, 1995.

HERCZOG, Johann. Il perfetto melodramma spirituale. L'oratorio italiano nel suo periodo classico. Rome: IBIMUS, 2013.

HILL, John Walter. Oratory Music in Florence, III: The Confraternities from 1655 to 1785. Acta Musicologica, 1986 (58) no. 1, p. 129-179.

MISCHIATI, Oscar. Per una storia dell'oratorio a Bologna: Tre inventari del 1620, 1622 e 1682. Collectanea historiae musicae, 1963 (III), p. 131-170.

MORELLI, Arnaldo. Il Theatro spirituale ed altre raccolte di testi per oratorio romani del Seicento. Rivista Italiana di Musicologia, 1986 no. 1, p. 61-143.

ROSAND, Ellen. Opera in Seventeenth-Century Venice: The Creation of a Genre. Berkeley-Los Angeles-Oxford: University of California Press, 2007. 
RYSZKA-KOMARNICKA, Anna. Judyta i Holofernes - oratoryjne odpowiedniki bohaterów barokowej opery, Amazonki i Tyrana. Polski Rocznik Muzykologiczny, 2012, p. 123-145.

RYSZKA-KOMARNICKA, Anna. Metastasio's 'La Betulia liberata' (1734) in the Context of Selected Late-Baroque 'trionfi di Giuditta' held in Rome. In La cultura del barroco español e iberoamericano y su contexto europeo, eds. Kazimierz Sabik - Karolina Kumor. Varsovia: Instituto de Estudios Ibericos e Iberoamericanos de la Universidad de Varsovia, 2010, p. 673-682.

SARNELLI, Mauro. Dai Barberini all'età dell'Arcadia. Nuova indagini sulla poetica drammaturgico-musicale sacra di Arcangelo Spagna. In Musikstadt Rom. Geschichte-Forschung - Perspektiven. Beiträge der Tagung »Rom - Die Ewige Stadt im Brennpunkt der aktuellen musikwissenschaftlichen Forschung « am Deutschen Historischen Institut in Rom, 28.-30. September 2004, ed. Markus Engelhardt. Kassel: Bärenreiter-Verlag, 2011, p. 263-305 (Analecta Musicologica, 45).

SARNELLI, Mauro. Percorsi dell'oratorio per musica come genere letterario fra Sei e Settecento. In Percorsi dell'oratorio romano. Da "historia sacra" a melodramma spirituale, ed. Saverio Franchi. Roma: IBIMUS, 2002, p. 137-197.

SARTORI, Claudio. I libretti italiani a stampa dalle origini al 1800. Catalogo analitico con 16 indici, vols. I-VII. Cuneo: Bertola\&Locatelli, 1990-1994.

SCARLATTI, Alessandro. La Giuditta, ed. Lino Bianchi. Roma: De Santis, 1964, p. 162-174.

SMITHER, Howard E. The Oratorio in the Baroque Era. Italy - Vienna - Paris. Chapel Hill: The University of North Carolina Press, 1977.

SPAGNA, Arcangelo. Oratorii overo melodrammi sacri con un discorso dogmatico intorno l'istessa materia, facs. ed. by Johann Herczog. Lucca: Libreria Musicale Italiana, 1993.

SPECK, Christian. Das Italienische Oratorium 1625-1665: Musik und Dichtung. Turnhout: Brepols, 2003.

STAFFIERI, Gloria. L'oratorio musicale a Roma (1683-1713): documenti, aspetti e problemi, MA thesis. Roma: Università di Roma "La Sapienza", 1985/86, vol. I, p. 110-117.

ZANETTI, Roberto. La Musica Italiana nel Settecento, vol. 2. Torino: Bramante Editrice, 1978. 